\title{
WEATHERING AND MORPHOSTRATIGRAPHIC EVIDENCE FOR FOUR GLACIATIONS IN THE HENTY RIVER BASIN, WESTERN TASMANIA
}

\author{
by Paul C. Augustinus and Eric A. Colhoun
}

(with two tables and three text-figures)

Augusmons, P.C. \& Cor.houn, E.A., 1995 (30:vi): Weathering and morphostratigraphic evidence for four glaciations in the Henty River Basin, western Tasmania. Pap. Proc. R. Soc. Tasm. 129: 53-58. https://doi.org/10.26749/rstpp.129.53 ISSN 0080-4703. Department of Physical Sciences, University of Tasmania, PO Box 1214, Launceston, Tasmania, Australia 7250 (PCA); Departmem of Geography, University of Newcastle, Callaghan, NSW, Australia 2'.308 (EAC).

The Quaternary glacial histories of the Pieman and Henty River Basins have largely been developed by using post-depositional weathering criteria to identify and map the drift sheers. Application of rclative dating techniques, such as percentage absorption and specific gravicy of Cambrian volcanic clasts, forces a reinterpretation of palaeomagnetic evidence previously offered for the age of the Henty Drift, so that at least three pre-Last Glacial Maximum (LGM) drift sheets can be recognised. The deeply weathered and most extensive (but with limited exposure) Berry Creek Drift is possibly a correlative of the Bulgobac/Linda Drift and can be clearly distinguished from the slightly less extensive but more widely exposed Henty Drift. A minimally weathered and spatially restricted drift, termed the Julia Drift, is exposed beyond and pre-dates the LGM cnd moraines.

Keywords: glaciation, Henty Basin, relative dating, correlation, drift sheets, Tasmania.

\section{INTRODUCTION}

The Late Cenozoic glacial history of western Tasmania has been reviewed in a number of studies (Colhoun 1985a, Colhoun \& Fitzsimons 1990, Kiernan 1990a, Fitzsimons et al. 1993). Although the essential elements of glacial histories of each major drainage basin have been elucidated (Pieman Basin - Augustinus \& Colhoun 1986, Augustinus et al., 1994; Henty Basin - Colhoun, 1985a,b; the King Basin Fitzsimons \& Colhoun 1991, Fitzsimons et al. 1993), the timing of the identified glacial events from each basin is poorly constrained, due to the general absence of datable material. As a consequence of this uncertainty, correlations between glacial sequences, even from adjacent valleys are problematical.

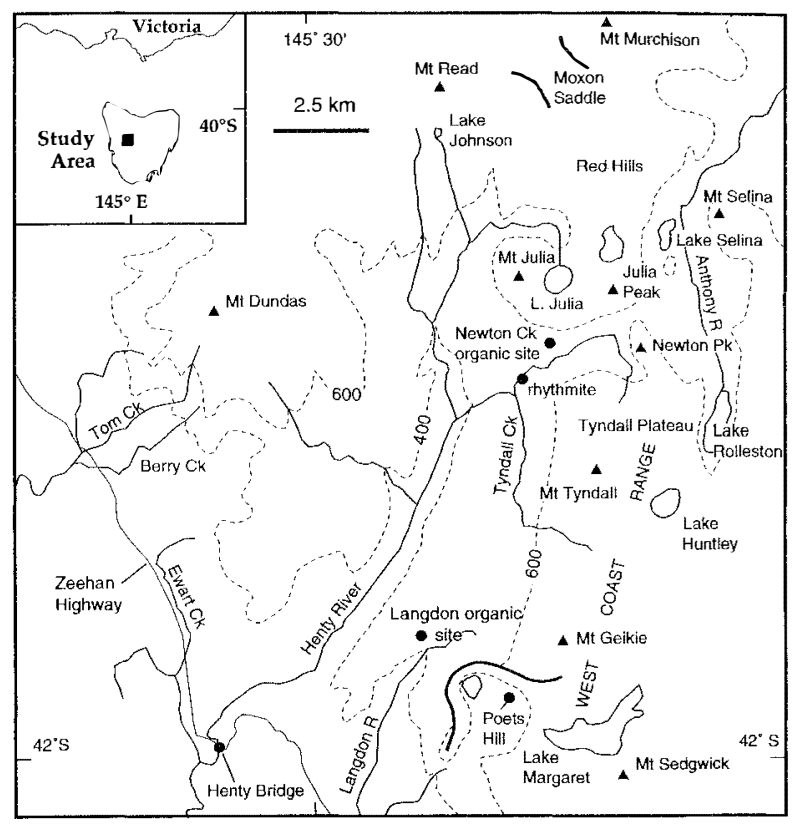

FIG. 1-Location map, Henty River Basin
Correlations between the sequences from each of the basins have necessarily been made on the basis of postdepositional weathering criteria, such as thickness of weathering rinds developed on clasts of Jurassic dolerite, and relative degrees of till matrix alteration and soil development. Use of these relative dating (RD) techniques enabled the discrimination of the sediments deposited by different glacial events. However, use of RD criteria (such weathering rind thickness variations) for correlation of glacial sequences between even adjacent drainage basins is hampered by the general absence of dolerite in the glacial sediments from some valleys. In addition, climatic and topographic drainage differences pertaining between basins influence the rate of weathering and, hence, the validity of correlations made on the basis of such criteria (Kiernan 1990b).

This paper assesses the use of several post-depositional weathering criteria in mapping the glacial drifts of the Henty River Basin (fig. 1) and attempts to correlate the drift sheets defined with those mapped in the adjacent Pieman Basin. Since Jurassic dolerite is absent from most of the Henty Basin Drifts, alternative RD criteria had to be used, including percentage absorption and specific gravity variations in Cambrian volcanic clasts from glacial diamictons. We combine the RD information with palaeomagnetic evidence to construct a correlation of the glacial sequences between the basins that is more reliable than any hitherto.

\section{GLACIAL HISTORY OF THE HENTY RIVER BASIN}

The glacial history of the Henty Basin was first studied by Bowden (1974), and glacial landforms were mapped as the product of one glaciation. The first evidence that more than one glaciation had occurred in the Henty Basin came from ${ }^{14} \mathrm{C}$ dates on lacustrine organic clays overlying weathered till at Henty Bridge (fig. 1) (Colhoun 1985b). Dates of 23640 \pm 1030 yrs (GaK 5597) to >34 600 yrs BP (GaK 5595) 
confurmed that the underlying deposits predated the Last Glacial Maximum (LGM); the relative degree of till clast weathering and the thick, partially weathered screes overlying the Henty sediments strongly suggested a pre-Last Interglacial, rather than an early Last (Margaret) Glaciation age (Colhoun 1985b). This was supported by analyses of recently discovered interglacial deposits at Langdon River that indicated a mixed wet forest at the site (Colhoun et al. 1988). The site is located $1 \mathrm{~km}$ beyond the LGM end moraines and $5 \mathrm{~km}$ upvalley from the limits of the Henty Glaciation. Wood from the surface of the interglacial deposit was dated at $41900+1000,-900 \mathrm{yrs}$ BP (SUA 2277), and an aminoacid assay suggested an age of Isotope Stage 7 , with the Henty Glaciation inferred to predate this.

Colhoun \& Fitzsimons (1990) and Pollington (1991) suggested that reversed detrital remanent magnetisation recorded in rhythmites at Tyndall Creek (fig. 1), in sediment regarded as being of Henty Glaciation affinity, indicated that the deposits at Henty Bridge may pre-date those elsewhere in the West Coast Range that have been referred to as belonging to the Henty Glaciation. However, reexamination of the Tyndall Creek site by the authors indicated that the stratigraphy of the site is more complex than had previously been recognised. Deeply weathered glacial sediments, possibly the equivalents of the still older Linda (King Valley) and Bulgobac (Pieman Valley) Drifts, had not previously been recognised in the Henty River Basin but were found to form most of the Tyndall Creek section, being buried by only $2 \mathrm{~m}$ of Henty-type till.

An organic deposit at Newton Creek (fig. 1) provided a date of $>33950$ yrs BP (Beta 21759), with the trend towards warming, indicated by the pollen and macrofossil record, suggesting that the deposit may represent an interstadial during the early part of the Last Glacial Stage (Colhoun et al. 1993). The timing of the LGM from the Pieman and Henty Basins has recently been elucidated from pollen analysis of shallow cores from Lake Selina (fig. 1) (Pola, Colhoun \& Barton, unpubl. data). A change from last interstadial to the commencement of climatic deterioration and onset of the LGM has been inferred at 25000 yrs BP at Tullabardine (Colhoun \& van de Geer 1986), with the end of the LGM at Lake Selina dated at $14200 \pm 230$ yrs BP (SUA 3040). Similarly, at nearby Lake Johnston, the deglaciation of the basin had occurred by $9430 \pm 110$ yrs BP (SUA 2987) (Anker 1991), and by at least $11420 \pm 770$ yrs BP (GaK 6297) at Poets Hill Lake adjacent to the Hamilton End Moraine (Colhoun 1992). The LGM glaciers did not penetrate west of the West Coast Range, unlike the older and far more extensive Boco (formerly the Boco 2 Glaciation of Augustinus \& Colhoun 1986), Bobadil (formerly the Boco 1 Glaciation of Augustinus \& Colhoun 1986) and Bulgobac glaciers in the Pieman Basin (Augustinus \& Colhoun 1986, Augustinus et al. 1994). Sharp-crested LGM end moraines are found below Mts Read and Murchison and at the southern end of the Tyndall Plateau (the Hamilton End Moraine) (fig. 1). No evidence for an early Last Glacial advance, such as that argued for the King Valley (Chamouni Glaciation) by Fitzsimons \& Colhoun (1991), has been recognised from the Henty Basin.

\section{METHODS USED IN STUDY}

The application of relative dating techniques to the discrimination and mapping of drift sheets from the Henty Basin is largely hampered by the paucity of dolerite and other lithologies that develop sharply defined weathering rinds. The absence of dolerite from the upper Henty Basin means that the quantification of weathering rind thicknesses, so successful in allowing the mapping of glacial drift sheets elsewhere in western Tasmania (i.e. Kiernan 1983, Kiernan 1989) was not applicable here. The degree of weathering of Cambrian volcanic clasts from the Pieman Basin was used by Auguscinus \& Colhoun (1986) to discriminate successfully between drift shects of different relative ages when used in conjunction with a range of other post-depositional weathering criteria. Cambrian volcanics (together with Ordovician conglomerates) dominate the upper Henty Basin and are the major source of clasts found in the drifts there.

Hence, we use the relative degree of Cambrian volcanic clast alteration as a tool to enable identification of drift sheets of differing relative ages from the Henty Basin, and for correlation of the glacial drifts mapped from both the Pieman and Henty River Basins. The relative degree of clast alteration was quantified by following the methods detailed in McGregor (1981) and Augustinus \& Colhoun (1986). These methods are:

(1) percentage absorption (\%Ab) of water by volcanic clasts, which refers to the volume of water that a rock clast can absorb (the more water the clast absorbs, the more it has been altered by the removal of easily weathered minerals); and (2) specific gravity (SG) of volcanic clasts, which also varies with degree of clast weathering, as unstable minerals are altered and the products removed.

The variations in $\% A b$ and $S G$ reflect porosity and void development, and indicate the degree of weathering of the host drift (McGregor 1981). Where possible, clast samples were taken from a uniform $1 \mathrm{~m}$ depth in the drift exposures. The weathering front was in all cases deeper than the sample sites, with little apparent variation in degree of clast alteration down profile, so any variation in sampling depth probably had no significant influence on the results. One to two kilogram samples of $4-8 \mathrm{~cm}$ diameter Cambrian volcanic clasts were taken from the drift at each site, so that mineralogical (crystal size and composition) variations between the clasts could be averaged out.

Other post-depositional weathering criteria used for the differentiation of Henty Basin drift sheets include till matrix colour, degree of Fe/Mn oxide panning in the drift, dolerite weathering rind thicknesses (where appropriate) and moraine morphology. The details of these techniques were given in Augustinus \& Colhoun (1986) and are used here to support drift separation based on qualitative observations of relative degrees of drift modification.

\section{RESULTS AND DISCUSSION}

Observations on the relative degree of weathering of the drifts from the Henty River Basin suggest the development of at least three distinct drift sheets of differing relative age beyond the LGM limits. The most useful methods for separating the drift sheets were quantitative evaluation of state of clast alteration, degree of iron panning and clast $\mathrm{Fe}$ oxide staining, topographic position and degree of modification of moraine morphology (table 1). 
TABLE 1

Late Cenozoic glacial stratigraphy, Henty River Basin, western Tasmania

\begin{tabular}{|c|c|c|c|c|c|c|c|c|}
\hline $\begin{array}{l}\text { Glacial } \\
\text { events }\end{array}$ & $\begin{array}{l}\text { Magnet- } \\
\text { isation }\end{array}$ & $\begin{array}{c}{ }^{14} \mathrm{C} \\
\text { (kyrs) }\end{array}$ & $\begin{array}{l}\text { Amino } \\
\text { acid }\end{array}$ & $\begin{array}{l}\mathrm{Jdl}{ }^{*} \text { weathering } \\
\text { rind thickness } \\
\text { max. (min) }\end{array}$ & $\% A b$ & $\begin{array}{l}\text { Specific } \\
\text { gravity }\end{array}$ & $\begin{array}{l}\text { Degree of } \\
\text { Fe oxide } \\
\text { development }\end{array}$ & $\begin{array}{l}\text { Wearhering } \\
\text { front }\end{array}$ \\
\hline Margaret & & 18.8 & & -- & - & - & none & $<1$ \\
\hline Interstadial ${ }^{\dagger}$ & & $>34$ & & & & & & \\
\hline Julia Drift & & & & - & - & - & minor Fe & $<2$ \\
\hline $\begin{array}{l}\text { Langdon } \\
\text { Interglacials }\end{array}$ & & $>41.9$ & Stage 7 & & & & & \\
\hline Henty Drift & & $>34.6^{\circ}$ & & 15 & $2.7-14.5$ & $2.10-2.45$ & thin Fe pans & $2-4$ \\
\hline $\begin{array}{l}\text { >/83 kyrs } \\
\text { Berry Creek } \\
\text { Drift }\end{array}$ & reversed & & & 30 & $14.4-20.8$ & $1.95-2.05$ & thick Fe pans & $\begin{array}{c}\text { not exposed } \\
>4\end{array}$ \\
\hline
\end{tabular}

* Jdl = dolerite. $\$$ Colhoun (1985a). $\ddagger$ Colhoun et al. (1993). $\$$ Colhoun et al. (1988).

Solhoun (1985b). \# Pollington (1991).

The presumed youngest and least extensive of the drift sheets displays minimal clast alteration, absence of $\mathrm{Fe} / \mathrm{Mn}$ oxide panning and limited Fe staining of clasts. The till matrix is weathered to yellowish grey (2.5YR6/1; Standard Soil Colour Chart) and a $2 \mathrm{~m}$ weathering front was observed (table 1). The morphology is hummocky and minimally modified, and is only developed on the higher parts of the Henty Surface, southwest of Mt Julia (fig. 2). This drift is termed the Julia Drift, after the type site on Howards Road $600 \mathrm{~m}$ west of $\mathrm{Mr}$ ) Julia (Selina 3836 - 1:25 000; Universal Grid Reference 55G CP 801615). It is located beyond the limit of the LGM moraines on the Tyndall Range and Mts Murchison and Read, and the $>33950$ yrs BP date from Newton Creek (Colhoun et al. 1993) indicates that the drift has an age beyond the limit of ${ }^{14} \mathrm{C}$.

Beyond the Julia Drift, on the Henty Surface, is the most extensive and best displayed of the drift sheets - the Henty Drift (fig. 2). The clast composition is dominated by Cambrian volcanics and Ordovician Owen Conglomerate, with the former displaying a significantly greater degree of clast alteration than is displayed by the Julia Drift. No dolerite was encountered, and Fe/Mn oxide panning is common, with clay skins commonly developed on volcanic clasts (table 1 ). The till matrix is weathered to reddish brown (2.5YR4/8) and the depth to weathering front measures $2-4 \mathrm{~m}$. The drift surface is hummocky, and a nearly continuous ground cover is maintained, although without clear end moraines. This drift sheet is best displayed at the Henty Bridge and at the Anthony Dam RoadZeehan Highway intersection and is considered to represent the Henty Drift described by Colhoun (1985a, b). Consequently, the name Henty is maintained for the drift at this site, and Henty Bridge remains the type site.

One kilometre north of Henty Bridge, on the Zeehan Highway, the drift exposures change: moderate degrees of weathering give way to a deeply altered diamicton containing totally decomposed Cambrian volcanic clasts of up to $0.25 \mathrm{~m}$ diameter. The till matrix is weathered to bright yellowish brown (10YR6/8) and strong Fe oxide panning is developed (table 1). The depth to the weathering front was not observed in this drift. The drift exposure at Tom
Creek and adjacent Berry Creek contains up to $40 \%$ dolerite clasts with alteration rims of up to $3 \mathrm{~cm}$ thickness, but most exposures along this section of highway contain only occasional dolerite clasts. The drift remnants are fragmentary, and no moraine morphology has been preserved. Colhoun (1979) termed this the Tom and Berry lobe of the Henty Glaciation.

This drift sheet persists beyond the limits of the Henty Drift and represents the most extensive glacial episode to have drained into the Henty Basin via the Tyndall Plateau (fig. 2). Previously undefined, this drift sheet is termed

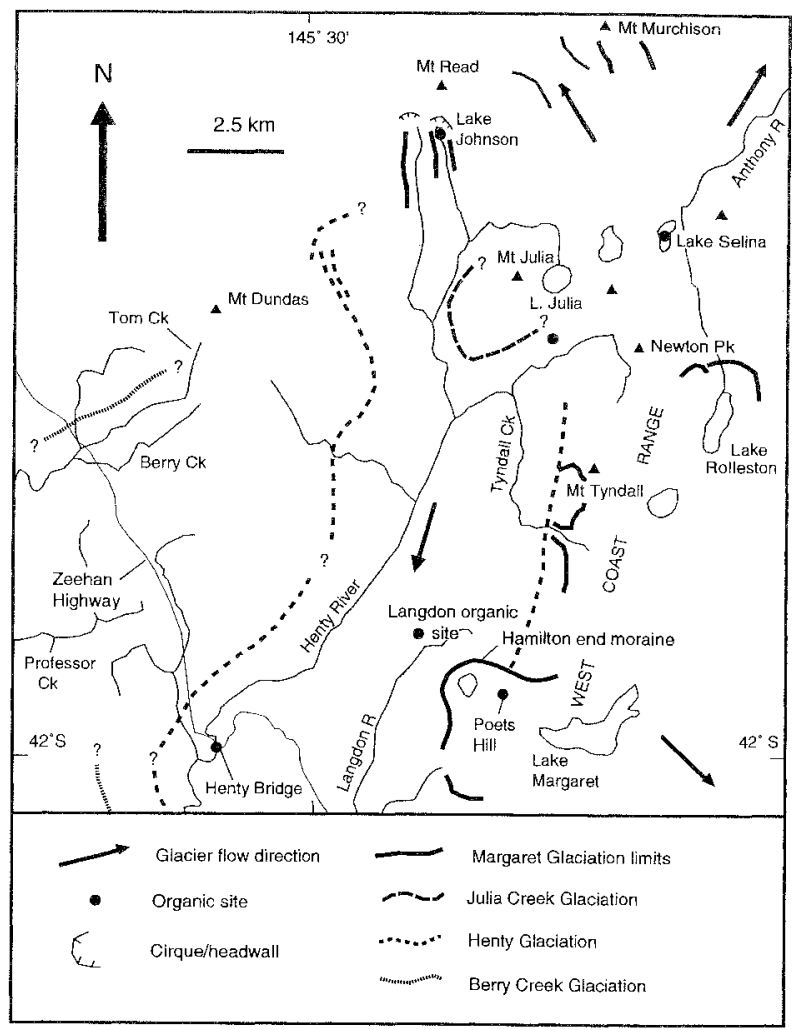

FIG. 2-Glacial drift limits, Henty River Basin 
here the Berry Creek Drift, after its type site immediately north of Berry Creek on the Zeehan Highway (Oceana 3635 - 1:25 000; UGR 55G CP702568). Hammond (1985) recognised deeply altered clasts in till at Professor Creek (fig. 2) and suggested that the deposits at this site pre-date the Henty till at Henty Bridge and may correlate with the Linda till from the King Valley, because of a similar gross state of clast weathering. Hence, the deeply altered till from this site probably correlates with the Berry Creek Drift exposed on the nearby Zeehan Highway and further supports the subdivision of the Henty drift into at least two glacial drifr sheets of differing relative age.

\section{SUPPORT OF DRIFT SHEET MAPPING USING PERCENTAGE ABSORPTION AND SPECIFIC GRAVITY}

Augustinus \& Colhoun (1986) plotted \%Ab against SG values from Cambrian volcanic clasts in the Pieman River Basin as a scatter graph, and obtained a straight line relationship with three identifiable populations. These groupings supported other post-depositional weathering evidence for at least three distinct drift sheets (Augustinus \& Colhoun 1986). The \%Ab and SG data showed that the penultimate Boco Glaciation Drift could be discriminated clearly from the much more extensively altered Bulgobac Drift. The latter displays reversed detrital magnetisation and is hence $>783$ kyrs old (Pollington 1991, Baksi etal. 1992), although the overlap between the $S G$ and $\% A b$ results from the Bobadil Drift (formerly termed Boco I in Augustinus \& Colhoun 1986) and the Bulgobac and Boco Drifts suggests that the method will only allow the confident discrimination of drifts separated by a long weathering interval equal to at least one glacial-interglacial cycle. The discrimination power of the method declines with variability in degree of clast alteration between sites.

Figure $3 \mathrm{~A}$ shows the \%Ab versus SG plot for all sites from the Pieman Basin, whilst figure $3 \mathrm{~b}$ shows both the Henty and Pieman River Basin drift sheet data. Examination of figure $3 \mathrm{~B}$ indicates that the Henty Drift data correlate well with the Bulgobac and Bobadil Drift results from the Pieman Basin, with the Boco sites generally having significantly lower $\% \mathrm{Ab}$ and higher SG values. This suggests a greater relative age for the widespread Henty Drift exposed along the Anthony Dam Road than for the Boco Drift from the Pieman Basin.

The Berry Creek Drift displays a very high degree of weathering and clast alteration with many of the Cambrian volcanic clasts of up to $0.25 \mathrm{~m}$ diameter weathered to ghosts. Volcanic clasts selected from six sites in this deeply altered diamicton were examined; their \% Ab and SG values are plotted in figure $3 \mathrm{~b}$. At all but one site, the clasts display a significantly greater degree of weathering than than do those from the Henty Drift, and the degree of alteration is comparable to that of the Bulgobac Drift from the Pieman Basin. This is supported by the degree of weathering of dolerite clasts from these sites. Dolerite clasts comprise up to $40 \%$ of the ice-proximal coarse gravel exposed immediately south of Tom Creek (fig. 2) and weathering rinds up to $30 \mathrm{~mm}$ thick were measured, although most of the clasts have been disturbed so that the "true" dolerite weathering rind thicknesses have probably not been measured.
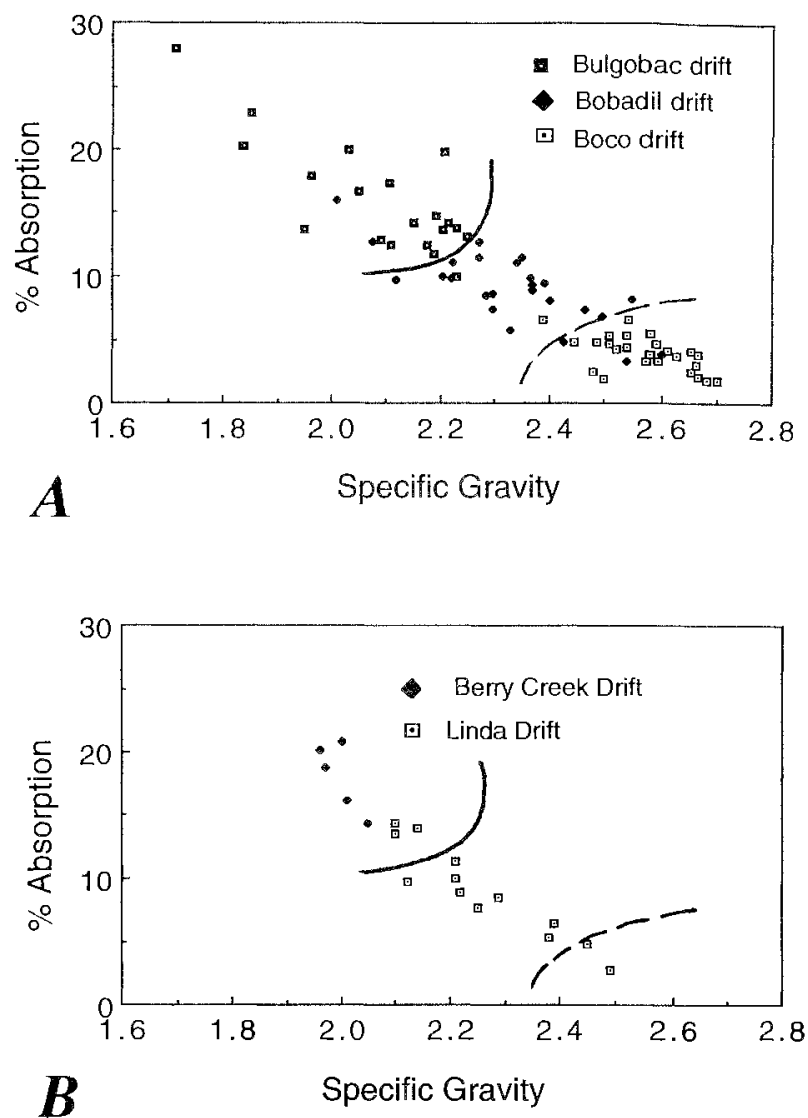

FIG. 3-Plots of specific gravity versus percentage absorption for volcanic clasts: (A) clast values from Pieman River Basin sites; (B) clast values from the Henty River Basin. Lines delineating fields representing range of specific gravity and \% absorption values for the Pieman Basin drifts indicated: solid lines = Bulgobac Drift, dashed lines = Boco Drift.

\section{DATING AND INTER-BASIN CORRELATION OF THE DRIFT SHEETS}

Measurement of SG and \%Ab of volcanic clasts from the glacial drift sheets in the Pieman and Henty River Basins supports the mapping of several distinct drift sheets using several other post-depositional weathering criteria. In the Pieman Basin, clear differentiation berween the Boco and Bulgobac Drifts is possible, although overlap with both occurs when volcanic clasts from the Bobadil Drift are examined. The two extensive glacial drifts from the Henty Basin can be more confidently mapped on the basis of differences in \%Ab and SG and assigned to drift sheets of different relative age.

The most extensive and deeply weathered drift from the Henty Basin displays a degree of clast alteration comparable with that of the Bulgobac Drift from the Pieman Basin, although there is significant overlap between the groupings, as would be expected given the variability in clast mineralogy, topography and microclimate at each site. Hence, the older, deeply weathered drift from the Henty Basin (Berry Creek Drift) is tentatively correlated with the Bulgobac Drift from the Pieman Basin (table 2). Dolerite is common in the Berry Creek Drift but not the Henty 
Drift: it was probably derived from supraglacial debris added to the lateral margins of the extensive Berry Creek piedmont glacier when the western margin abutted the dolerite-capped Mt Dundas.

Presence of reversed detrital remanent magnetisation (DRM) in Henty Drift glaciolacustrine sediments from Tyndall Creek suggested to Colhoun \& Fitzsimons (1990) that the Henty Glaciation may pre-date the BrunhesMatuyama boundary. However, re-examination of the site by the present authors indicates that the rhythmites contain ice-push structures and display clear evidence that the basal rhythmites, from which the reversed DRM results were obtained, were overridden. The basal diamicton displays a degree of clast alteration comparable to that of the Berry Creek Drift, whilst the upper diamicton displays a significantly lower degree of clast alteration and is identical to the Henty Drift mapped elsewhere on the Henty Surface. Hence, the site is interpreted as representing Berry Creek Drift (including glaciolacustrine rhythmite) with an age $>783$ kyrs, which was later overridden by the Henty Glacier, resulting in deformation of the older rhythmites. This phase terminated with the deposition of indurated basal till of Henty Glaciation affinity. No rhythmite has been found associated with the Henty Drift in the Henty Valley.
The Henty Drift has the most widespread exposure of any of the Henty Basin drifts and displays clast alteration values comparable with those of the Bobadil Drift from the Pieman Basin; a tentative basin-wide correlation between the two drifts is suggested here (table 2). This correlation is supported by an amino-acid assay on wood from the Langdon River organic site, which is developed on the floor of a meltwater channel lined with laminated silts and clays associated with the Henty Drift. The amino-acid assay suggests Isotope Stage 7 age for the organic site (B.J. Pillans, pers. comm, 1988) and at least Stage 8 for the Henty Glaciation. The Bobadil Glaciation has been dated to lsotope Stage 8 on the basis of bracketing U/Th dates of $166+41,-33$ kyrs (LH 2460) and $279+100,-65 \mathrm{kyrs}$ (LH 2461) (Augustinus et al. 1994). If the correlations between basins based on post-depositional weathering criteria are correct, the Henty Glaciation can be more securely assigned to Isotope Stage 8 than to Stage 6, as suggested previously (Colhoun 1985a,b).

The Bobadil Drift from the Pieman Basin displays normal DRM and is $<783$ kyrs (Pollington 1991, Augustinus et al. in press). U/Th dating of ferricrete bands associated with Bobadil Glaciation sediments from the Boco Plain indicates a probable Isotope Stage 8 age for the glacial event

TABLE 2

Late Cenozoic glaciations of Pieman and Henty River Basins

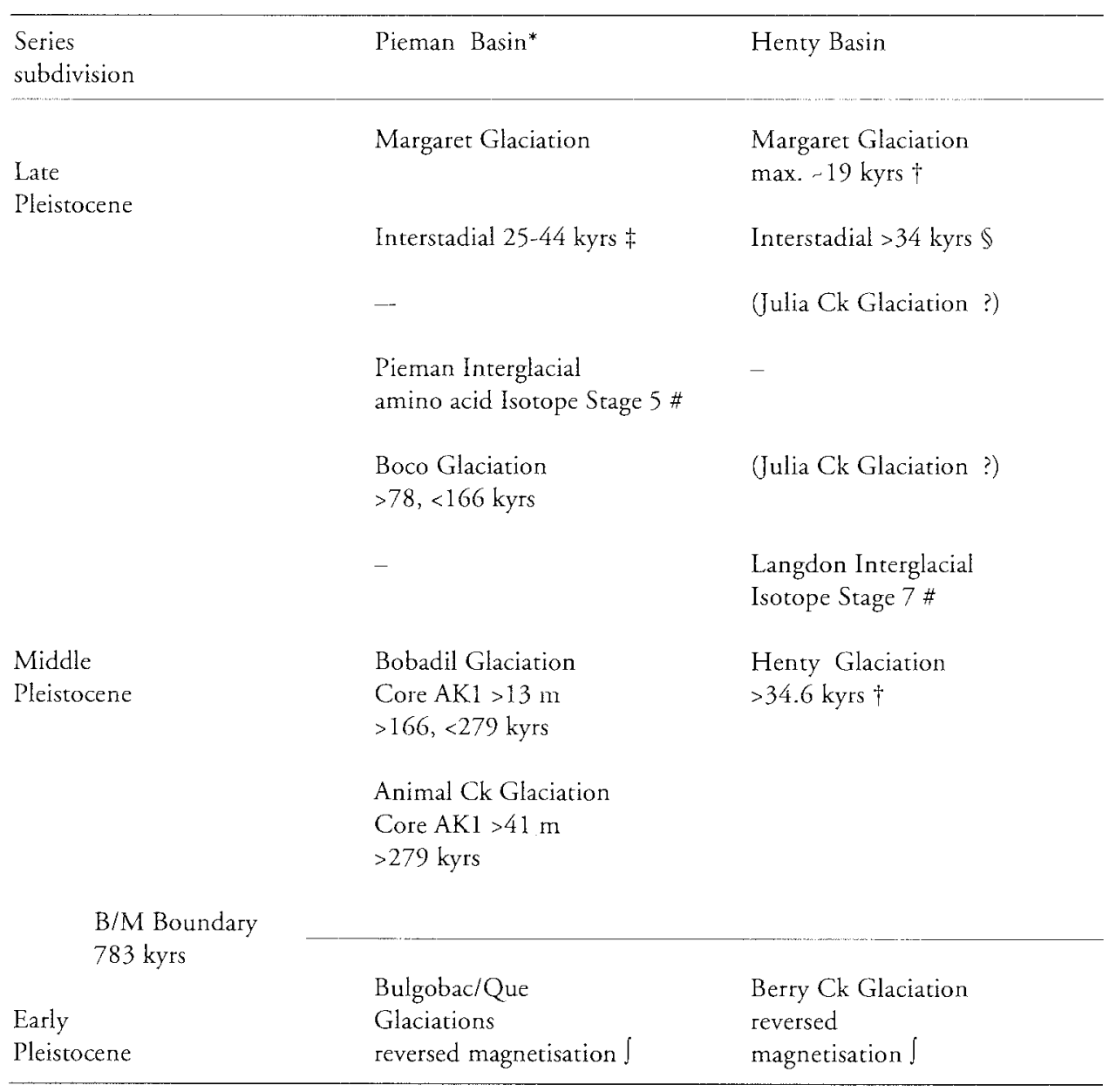

* Augustinus et al. (1994). † Colhoun (1985a). † Colhoun \& van de Geer (1986).

$\$$ Colhoun et al. (1993). I Colhoun \& Fitzsimons (1990). \# Colhoun et al. (1988).

$\int$ Pollington (1991).

AKl refers to Pasminco drill core from Boco Plain, with depths to U/Th dated horizons. 
(Augustinus et al. 1994). The Bobadil Drift is clearly of middle Pleistocene age, and correlation between the Bobadil and Henty Drifts seems reasonable on the basis of the amino-acid assays and clast weathering data from the Henty Basin (table 2). However, it is not possible to exclude correlation of the Henty Drift with the younger Boco Drift (Isotope Stage 6) from the Pieman Basin without better dating of the Henty Basin sequences.

The Julia Drift extends beyond the LGM end moraines and displays a distinctly lower degree of post-depositional alteration than the much more extensive and more weathered Henty Drift (table 1). Dating of this drift is not possible at this time. It could represent either an early Last Glacial ice advance, similar to that postulated for the Chamouni Formation from the King Valley (Fitzsimons \& Colhoun 1991), or it could belong to Isotope Stage 6. In the absence of firm dating of these drifts, it is not possible to determine the age with confidence.

\section{CONCLUSIONS}

Re-evaluation of the glacial stratigraphy of the Henty Basin has enabled the mapping of at least three drift sheets of preLast Glacial Maximum age, using relative degree of clast alteration, Fe panning, degradation of the moraine morphology and topographic position. The Berry Creek Drift represents the oldest and most extensive glaciation identified in the basin, although its distribution is fragmentary, as is the case with the similarly extensive Bulgobac Glaciation from the Pieman Basin.

The Henty Drift is much more widespread, is tentatively correlated with the Bobadil Drift from the Pieman Basin and is dated to the middle Pleistocene. The Henty Drift pre-dates Isotope Stage 7, and, presuming that the weathering evidence for correlation between the Henty and Bobadil Drifts is valid, an Isotope Stage 8 age can be assigned to both drifts. The Julia Drift is restricted in extent, displays minimal clast and matrix alteration and is located well beyond the distinct LGM (Margaret Glaciation) end moraines below Mt Read, Mt Murchison and the Tyndall Plateau. Dating of this drift is problematical, since weathering evidence suggests an age younger than the Henty Drift, but no datable material has been found to test this interpretation.

Although the measurement of clast SG and \%Ab does not permit discrimination between drifts, unless one has been exposed to prolonged periods of weathering equivalent to at least the duration of one interglacial episode, it does allow clear separation of the middle Pleistocene Henty/ Bobadil from the early Pleistocene Berry Creek/Bulgobac Drifts. Although the drifts from the Henty Basin are mostly devoid of dolerite clasts, it has been shown that these methods, when used with at least one other relative-dating test, provide the best means of differentiation and correlation between the drift sheets.

\section{REFERENCES}

ANker, S.A., 1991: Pollen and vegetation history from Lake Johnson in western Tasmania. Unpubl. BSc Hons thesis, Department of Geography, University of Newcastle.
Augustinus, P.C. \& Colnoun, E.A., 1986. Glacial history of the upper Pieman and Boco valleys, western Tasmania. Aust. J. Earth Sci. 33: 181-191.

Augustinus, P.C., Short, S.A. \& Colhoù, E.A., 1994: Pleiscocene stratigraphy of the Boco Plain, western Tasmania. Aust. J. Earth Sci. 41: 581-591.

Augustinus, P.C., Poldington, M.J. \& Colhoun, E.A., in press: Magnetostratigraphy of the Late Cenozoic glacial sequence, Pieman River basin, western Tasmania. Aust. J. Earth Sci.

Baksi, A.K., Hsu, V., McWililams, M.O. \& Farrar, E., 1992: ${ }^{40} \mathrm{Ar} /{ }^{39} \mathrm{Ar}$ dating of the Brunhes-Matuyama geomagnetic field reversal. Geology 256: 356-357.

Bowden, A.R., 1974: The glacial geomorphology of the Tyndall Mountains, western Tasmania. Unpubl. BSc Hons Thesis, Department of Geography, University of Tasmania.

COI.HOUN, E.A., 1979: QUATERNARY EXCURSION TO NORTHWEST AND WEST TASMANIA. Department of Geography, Universicy of Tasmania, Hobart.

Colnoun, E.A., 1985a: Glaciations of the West Coasc Range, Tasmania. Quatern. Res. 24: 39-59.

Col.Houn, E.A., 1985b: Pre-Last Glacial Maximum vegetation history at Henty Bridge. New Phytol. 100: 681-690.

Colhoun, E.A., 1992: Late Glacial and Holocene vegetation history at Poets Hill Lake, western Tasmania. Aust. Geogr. 23: 11-23.

Coinoun, E.A. \& Fitzsimons, S.J., 1990: Late Cainozoic glaciarion in western Tasmania, Australia. Quatern. Sci. Rev. 9: 199-216.

Colhoun, E.A. \& van de Gere, G., 1986: Holocene to Middle Last Glaciation vegetation history at Tullabardine Dam, western Tasmania. Proc. R. Soc. London B229: 177-207.

Colmoun, E.A., van de Geer, G., Hill, R.S. \& Bird, T., 1988: Interglacial pollen and plant macrofossils from the Langdon River, western Tasmania. New Phytol. 111 : 531-548.

Colmoun, E.A., Benger, S.N., Frtzsimons, S.J., van de Geer, G. \& Hin., R.S., 1993: Quaternary organic deposit from Newton Creek Valley, western Tasmania. Aust. Geogr. Stud. 31: 26-38.

Colmoun E.A. \& Frtzsimons, S.J., 1990: Late Cainozoic glaciation in western Tasmania. Quatern. Sci. Rev. 9: 199-216.

Fitzsimons, S.J. \& Colhoun, E.A., 1991: Pleistocene Glaciation of the King Valley, western Tasmania, Australia. Quat. Res. 36: 135-156.

Fitzsimons, S.J., Colhoun, E.A., va.N de Geer, G. \& Pollington, M.J., 1993: The Quaternary geology and glaciation of the King Valley. Bull. Geol. Surv. Tasm. 68.

Hammond, A., 1985: Soils and glacial geomorphology of the Central West Coast Range, Tasmania. Unpubl. BSc Hons thesis, Geography Department, University of Tasmania.

KIERNAN, K. W., 1983: Weathering evidence for an additional glacial stage in Tasmania. Aust. Geogr. Stud. 21: 197-220.

KIERNAN, K.W., 1989: Multiple glaciation of the upper Franklin Valley, western Tasmania Wilderness World Heritage Area. Aust. Geogr. Stud. 27: 208-233.

KIERnAN, K.W., 1990a: The extent of Late Cenozoic glaciation in the Central Highlands of Tasmania, Australia. Arctic ér Alpine Res. 22: 341-354.

Kiernan, K.W., 1990b: Post-depositional modification as an aid to dating Tasmanian glacial deposits. Aust. Geogr. 21: 117.

MCGregor, G.R., 1981: Weathering characteristics of Late Pleistocene rills. NZ J. Geol. Geophys. 24: 107-113.

Pollington, M.J., 1991: Magnetostratigraphy of glacial lake sediments and dating of Pleistocene glacial deposits in Tasmania. Unpubl. MSc thesis, University of Tasmania, Hobart.

(accepted 13 December 1994) 